\title{
Tensions and Transitions in the Muslim World
}

\author{
Louay Safi
}

Lanham, MD: University Press of America, 2003. 230 pages.

Safi's text interrogates the potential of Islamic reform movements to articulate a democratic and pluralistic politics throughout the Middle East and the broader Islamic world. He begins by arguing that these reform movements exert the greatest influence in determining the direction of sociopolitical reforms in the Middle East, and, as a result, constitute a core movement from which to understand and interpret the dynamics of the region's cultural and sociopolitical reality. Furthermore, the author argues that in the contemporary Middle Eastern intellectual climate, Islamic reformists represent a synthesis between the opposing programs of moralist-Islamists on the one hand, and nationalist-secularists on the other. This synthesis constitutes the most viable and realistic program for genuine reform and for developing a pluralistic society and participatory politics. In support of this thesis, Safi divides the text into nine chapters constituting four interrelated parts: "Democratization and the Islamic State," "Visions of Reform," "Islamic Law and Human Rights," and "Islam in a Global Cultural Order."

The first part poses the question of whether democracy and pluralism can flourish in a society in which Islamic law commands the majority's allegiance. His answer is cautiously affirmative, as it depends on the rejuvenation of cultural and legal reforms grounded in a historical Muslim experience 
that offers the tools to transcend current political and cultural institutions. As such, both the secular state and Islamist movements preclude such a renewal: the former because its structures negate the possibility of pluralistic politics, and the latter because its merging of state structures with the communal structure of the historical Shari ah contradicts the nature of the Islamic polity as established by the Prophet.

These restrictions can be overcome through grounding the state in two pillars. First, this means severing the link between the state and the ummah, a separation necessary to ensure that the state and its institutions are not hijacked by particularistic interests or erected as obstructions to the Islamic community's spiritual and conceptual development. Such an Islamic state, which privileges the marshalling of state resources toward the Islamic community's spiritual goals, also has, as its second pillar, the concept of consensus (ijma '). Classical jurists viewed this concept as the fundamental principle that confers legitimacy upon the state. Therefore, the state gains its legitimacy insofar as it reflects the ummah's will.

Having defined the foundational qualities of a democratic Islamic state, Safi turns his attention to the two primary competing visions of reform in the Middle East: nationalist-secularist and moralist-Islamist. These two visions are distinguished by their respective preoccupations: nationalist-secularists are concerned with structural, procedural, and organizational change, whereas moralist-Islamist movements focus on moral, legal, and confessional reform. This latter strand is associated with three prominent Islamic reform thinkers, all of whom are associated with separate phases of Islamic reformism: Jamaluddin al-Afghani (the intellectual phase); Hasan al-Banna, founder of the Ikhwan movement (the populist phase), and Sayyid Qutb (the revolutionary phase). Together, the influence of these three thinkers - coupled with the decline of the nationalist-secularist project - has impacted arguments for the rationale for reform as well as various prescriptions of reform. Ultimately, Safi argues for what he terms a "development model" that integrates moral and technical elements belonging to both strands of reform. In other words, Islamic reform must emerge from a rereading and synthesis of these two historical approaches to reform.

The third part continues to develop the Islamic reformist approach by concentrating on the notion of Islamic law and its relation to contemporary Muslim society. Safi frames his discussion of legal reform within the context of debates over Islam and human rights. Taking up the question of Islam's compatibility with human rights, he details the Shari'ah's development in early Islamic jurisprudence and the eventual supplanting of Islamic 
law by classical legal theory. A major consequence of this shift in legal structure was the stifling of its development simultaneously with the development of Islamic society. In other words, Islamic jurists could not develop legal doctrines consistent with changing social realities.

While accepting that adopting the Shari'ah in contemporary times would lead to human rights violations, Safi forcefully argues for a legal reform grounded in the Muslims' religious commitments. Thus, a renewed Islamic conception of human rights in particular, and legal reform in general, must be tethered to the principles of human dignity and moral reciprocity found in Islamic legal scholarship, a comprehensive approach that is compatible with current social realities on the one hand, and is deeply grounded in Islamic jurisprudence on the other.

In examining western-Islamic relations in the final part, Safi provides a rather weak appraisal of the key features of these relations, concentrating his focus instead on the West's ideological hostility toward political Islam and the dynamics of American foreign policy. He expresses an idealistic admiration of American foreign policy and in the potential for constructive American global leadership vis-à-vis the Islamic world. This discussion exposes a vulnerability, namely, the weak treatment of politico-economic issues, which are so much at the forefront of current debates over reform.

Nevertheless, this final discussion does not reflect the rigor with which he addresses the substantive issues presented in the previous three parts. In fact, the text's strength lies in the author's utilization of a great deal of historical and contemporary evidence, in various languages and across academic disciplines, to support his arguments. He convincingly navigates through the moralist-Islamist and nationalist-secularist reform schools to propose an alternative Islamic political program.

Although the text could have benefited from a more critical recognition of the schisms within the intellectual trajectory of Islamic scholarship, it nevertheless is a valuable contribution to contemporary debates over Islamic reform in general and political Islam in particular. Safi's attempts to overcome the dichotomous and polarized notions of what an Islamic political program entails by concentrating on the rich experiences and intellectual traditions of Islamic reformism that are conducive to formulating and articulating a pluralistic and democratic politics is particularly useful to the reader.

Samer Abboud

Ph.D. Candidate, Middle East Studies Institute of Arab and Islamic Studies University of Exeter, United Kingdom 